\title{
InCidental MORTALITy OF FRANCISCANA DOLPHIN (Pontoporia blainVILLEI) in Argentina
}

\author{
Humberto L. Cappozzo ${ }^{1,2,}$; Maria F. Negri ${ }^{1}$; Fabián H. Pérez'; \\ Diego Albareda ${ }^{3}$; Florencia Monzón². And Javier F. Corcuera².
}

\begin{abstract}
Aвstract: La Plata River dolphin or franciscana, Pontoporia blainvillei, is an endemic small cetacean of the Southwest Atlantic coast. It is threatened all along its distribution by a sustained high level of incidental mortality in fisheries. Here we assess levels of franciscana bycatch in Argentine waters between 1997 and 2003. We surveyed 18 localities along the coast of the Buenos Aires Province, between General Lavalle $\left(35^{\circ} 06^{\prime} \mathrm{S}, 57^{\circ} 08^{\prime} \mathrm{W}\right)$ and Bahía Blanca (Puerto Rosales-Ingeniero White harbour: $\left.38^{\circ} 47^{\prime} \mathrm{S}, 62^{\circ} 16^{\prime} \mathrm{W}\right)$. We recorded data on incidental mortality, fishing gears and fishing effort through 209 personal interviews with fishermen. We estimated annual mortality, fishing effort and catch per unit of effort (CPUE) for each locality and period of time. Mortality was caused by gillnets and trawling gears, purse seine nets and shrimper gears. The total mortality estimated for 1997-2000 was 354 dolphins/year $(95 \%$ CI = 318-392) and 307 dolphins/year (95\% CI = 273-343) for 2002-2003. In the entire survey, CPUE of the northern coast of Buenos Aires Province (Bahía Samborombón and Cabo San Antonio) was significantly higher than CPUE for the southern coast (from Mar del Plata to Bahía Blanca estuary). In addition, CPUE of the northern coast decreased significantly throughout the years. This study suggested that even though the gears or fleet behaviour changed locally, Buenos Aires Province evidenced an overall mortality relatively constant during the survey. If we consider a minimum of 400 dolphins killed each year in fishing gear and the estimated population values of 15000 individuals for the Argentine coast; mortality represent more than $2 \%$ of the Argentine franciscana population, suggesting that it would be subject to decline. Trends in mortality need to be periodically monitored in this area in order to articulate programs of conservation for the species.
\end{abstract}

Resumen: El delfín del Río de la Plata o Franciscana, Pontoporia blainvillei, es un pequeño cetáceo endémico de la costa del Atlántico Sudoccidental. A lo largo de toda su distribución se encuentra amenazado por un alto nivel sostenido de mortalidad incidental en pesquerías. En este trabajo, se determinaron los niveles de captura incidental en aguas argentinas entre 1997 y 2003. Se relevaron 18 localidades de la costa de la Provincia de Buenos Aires, entre General Lavalle $\left(35^{\circ} 06^{\prime} \mathrm{S}, 5^{\circ} 08^{\prime} \mathrm{W}\right)$ y Bahía Blanca (Puerto Rosales-Ingeniero White: $38^{\circ} 47^{\prime} \mathrm{S}, 62^{\circ} 16^{\prime} \mathrm{W}$ ). Se registró información de mortalidad incidental, artes de pesca y esfuerzo pesquero a través de 209 encuestas personales con pescadores. Se estimó mortalidad anual, esfuerzo pesquero y captura por unidad de esfuerzo (CPUE), para cada localidad y período de tiempo. La mortalidad fue ocasionada por redes agalleras y de arrastre, redes de cerco y camaroneras. La mortalidad total estimada para 1997-2000 fue de 354 delfines/año (CI $95 \%=318-392)$ y 307 delfines/año (CI 95\% = 273-343) para 2002-2003. Durante todo el período de estudio, la CPUE de la costa norte de la provincia de Buenos Aires (Bahía Samborombón y Cabo San Antonio) fue significativamente más alta que la CPUE de la costa sur (desde Mar del Plata hasta el estuario de Bahía Blanca). Asimismo, la CPUE de la costa norte disminuyó significativamente a través de los años. Este estudio sugirió que aún cuando las artes de pesca y el comportamiento de la flota cambiaron localmente, la Provincia de Buenos Aires evidenció una mortalidad total relativamente constante durante el período de estudio. Si consideramos un mínimo de 400 delfines muertos por año en artes de pesca y los valores poblacionales estimados de 15000 individuos para la costa argentina; la mortalidad representa más de 2\% del stock de franciscanas de Argentina, sugiriendo que la población en este país sería vulnerable a declinar. Es necesario monitorear periódicamente las tendencias de mortalidad y es urgente obtener información sobre la identidad de los stocks en esta área a fin de articular programas de conservación para la especie.

Keywords: Franciscana, Pontoporia blainvillei, incidental mortality, gillnet fisheries, southwest Atlantic Ocean.

\section{Introduction}

La Plata River dolphin or franciscana (Pontoporia blainvillei) is an endemic small cetacean frequently caught in fishing nets in the southwest Atlantic coast. The species occurs from southeastern Brazil $\left(18^{\circ} 25^{\prime} \mathrm{S}\right.$; Siciliano, 1994) to, Golfo Nuevo, northern Patagonia

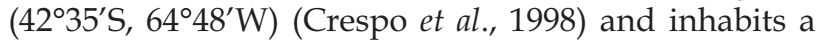
coastal marine habitat, usually in waters up to $30 \mathrm{~m}$ deep and approximately 25 to 30nm from shore (Praderi et al., 1989; Pinedo et al., 1989; Monzón and Corcuera, 1991). Incidental capture of this species occurs all along its geographical distribution (Corcuera, 1994; Secchi et al., 1997; Rosas et al., 2002). The bycatch in gillnets has been reported in the Buenos Aires area since the mid 1980s (Pérez Macri and Crespo, 1989). The southern area of Buenos Aires Province (from Puerto QuequénNecochea to Carmen de Patagones) was monitored between 1988 and 1994 where an overall fishing-related mortality of 237 individuals per year (CI 95\%: 208-269) was estimated (Corcuera, 1994), while the northern area (from Tigre, La Plata River Estuary, to Mar del Plata, Atlantic Ocean) was monitored in 1998 where an overall mortality of 228 individuals per year (CI 95\%: 200-260)

\footnotetext{
${ }^{1}$ Laboratorio de Ecología, Comportamiento y Mamíferos Marinos - Museo Argentino de Ciencias Naturales "Bernardino Rivadavia" (CONICET), Av. Ángel Gallardo 470, C1405DJR, Buenos Aires. Argentina.

${ }^{2}$ Estación Hidrobiológica de Puerto Quequén (MACN - CONICET), Quequén, Buenos Aires, Argentina.

${ }^{3}$ Acuario de Buenos Aires. Argentina.

*Corresponding author, e-mail: cappozzo@retina.ar or cappozzo@macn.gov.ar / 54-11-4984 6670 int 159 or 211.
} 
was estimated (Corcuera et al., 20004). Previous studies have shown that, in Argentina, artisanal vessels from small fishing camps located along the coasts of Buenos Aires Province pose more of a threat to franciscana than those based at large fishing harbours (Corcuera et al., 1994). Nevertheless, Bordino and Albareda (2004) ${ }^{5}$ estimated an annual mortality of about 410 dolphins in the northern Buenos Aires Province and in 651 for the entire artisanal fleet in Buenos Aires.

Franciscana abundance was estimated recently at 14234 individuals from aerial surveys for the Argentine coast (Crespo et al., 20066).

According to previous studies in the southern area, and current data, some harbours show changes in the fishing gears so incidental mortality might differ between years in each locality (Cappozzo et al., 19997; Corcuera et al., 20004). The aim of this study was to estimate an annual incidental mortality of franciscana dolphin in waters off Buenos Aires Province for the period 1997-2003.

\section{Material and Methods}

\section{Fieldwork}

We conducted three surveys between August 1997 and March 2003 and interviewed 209 fishermen along 18 localities in the Buenos Aires Province (Figure 1).

We considered as a fishing camp a non-permanent settlement along the coast formed by fishermen with 3-10 meter-long vessels dedicated to artisanal fishing, located farther from any harbour.

Data concerning fishing activities, such as fleet size, fishing gear, net length, mesh size and length of fishing season, as well as an approximate number of dolphins bycaught by different gears were obtained by interviewing fishermen from all localities (Figure 1 and Table 1). The interviews were conducted by one or two researchers twice or three times per fishing season surveyed (at the beginning, middle and end of each one). The information obtained was also confirmed and completed with data recorded by the Coast Guard of Argentina (Prefectura Naval Argentina).
We have only considered the fishing vessels that were operating at the moment of the study.

Previous studies in southern Buenos Aires Province have used this method to obtain data on marine mammal incidental mortality (Pérez Macri and Crespo, 1989; Corcuera et al., 1994; Crespo et al., 1994; Cappozzo et al., 19997). Nevertheless, in recent studies onboard observers were implemented in order to validate the incidental mortality estimation by interviews (Bordino and Albareda, 20045).

Between August 1997 and February 2000, 15 localities were monitored along the coast of Buenos Aires Province where a high mortality had been previously detected.

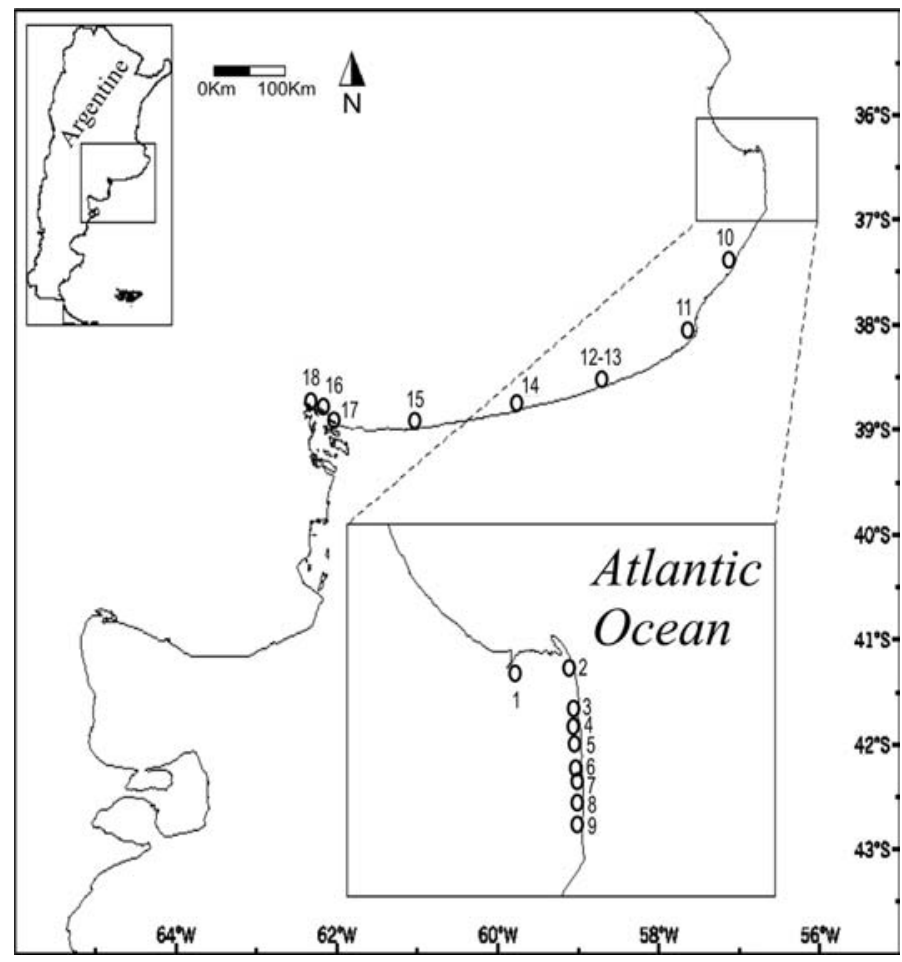

Figure 1: Study area with location of harbours (h) and fishing camps (fc) where dolphin mortality has been recorded along the coast of Buenos Aires Province, Argentina. Northern area: 1-General Lavalle (h), 2-San Clemente del Tuyú (h), 3- Las Toninas (fc), 4- Santa Teresita (fc), 5- Mar del Tuyú (fc), 6- Aguas Verdes (fc), 7- La Lucila del Mar (fc), 8- San Bernardo (fc), 9- Mar de Ajó (fc), 10- Villa Gessell (fc); Southern area: 11- Mar del Plata (h), 12-13 Quequén-Necochea (h), 14-Claromecó (fc), 15- Monte Hermoso (fc), 16Villa del Mar (fc), 17- Puerto Rosales (h), 18- Ingeniero White (h).

\footnotetext{
${ }^{4}$ Corcuera, J.F., Monzón, F., Cornejo, I., Pérez, J.E., Beilis, A., Gingarelli, M., Albareda, D. and Arias, A. (2000) Mortalidad de Pontoporia blainvillei en el norte de la Provincia de Buenos Aires. DT 25 in Report of the Third Workshop for Coordinated Research and Conservation of the Franciscana Dolphin (Pontoporia blainvillei) in the Southwestern Atlantic.

${ }^{5}$ Bordino, P. and Albareda, D. (2004) Incidental mortality of Franciscana dolphin Pontoporia blainvillei in coastal gillnet fisheries in northern Buenos Aires, Argentina. Paper SC/56/SM11 presented at the International Whaling Commission Meeting, Sorrento, Italy, July 2004, 7pp.

${ }^{6}$ Crespo, E. A., Pedraza, S. N., Grandi, M. F., Dans, S. L., Garaffo, G. (2006) Estimación de abundancia de Franciscana (Pontoporia blainvillei) en aguas argentinas e implicancias para su conservación. Page 15 in Abstracts, I Reunión Internacional sobre el Estudio de los Mamíferos Acuáticos SOMEMMA-SOLAMAC, 5-9 November, Mérida, México.

${ }^{7}$ Cappozzo, H. L., Monzón, F., Pérez, J. E. and Corcuera, J. F. (1999) Mortality of La Plata River Dolphin, Pontoporia blainvillei, in Southern Buenos Aires Province, Argentina (1998): Big changes that change nothing. Page 52 in Abstracts, 13th Annual Conference of the European Cetacean Society, 5-9 April, Valencia, Spain.
} 


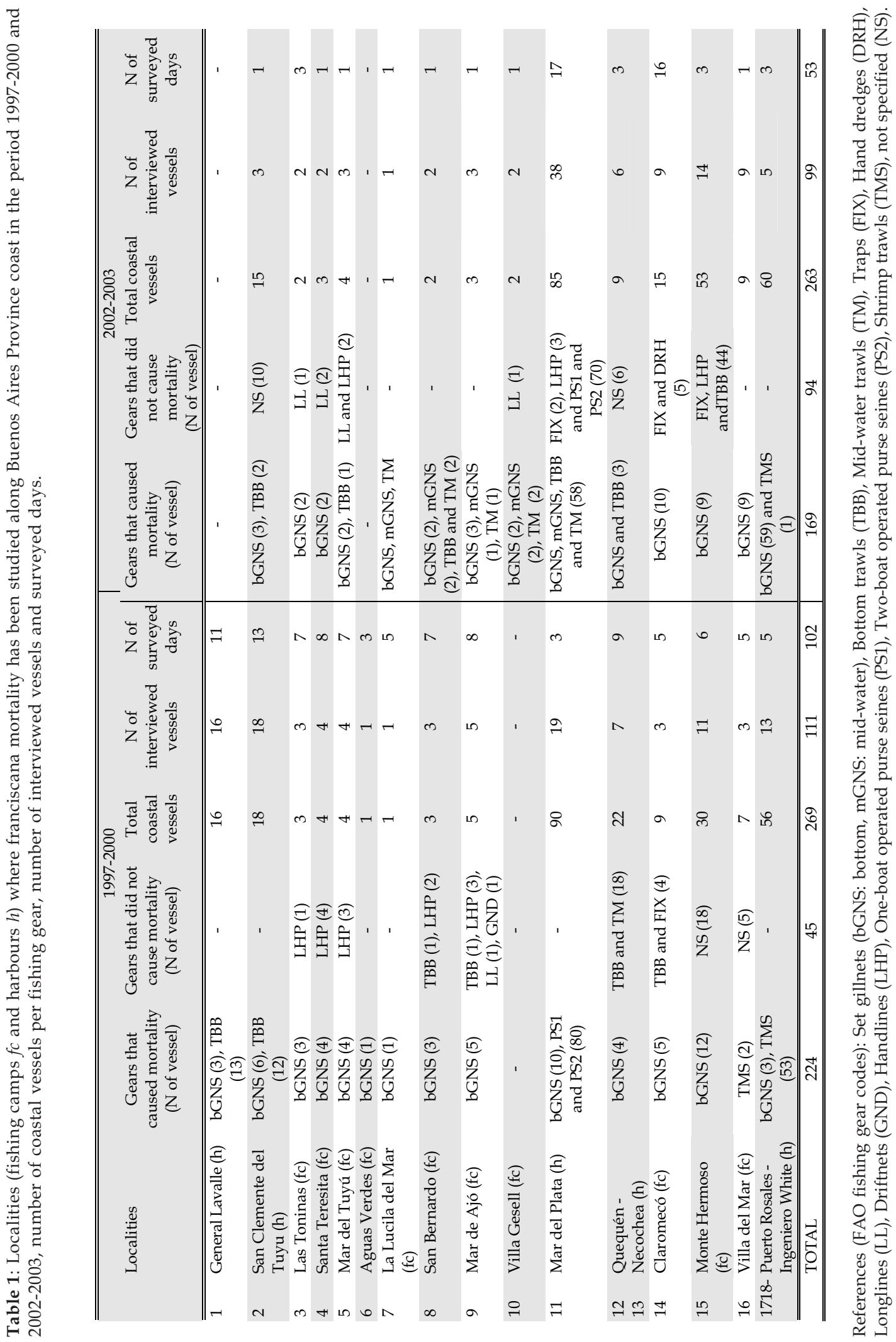


These localities include five fishing harbours: General Lavalle (fishing location 1), San Clemente del Tuyú (2), Mar del Plata (11), Quequén-Necochea (12-13) and Puerto Rosales-Ingeniero White (17-18); and 10 fishing camps: Las Toninas (3), Santa Teresita (4), Mar del Tuyú (5), Aguas Verdes (6), La Lucila del Mar (7), San Bernardo (8), Mar de Ajó (9), Claromecó (14), Monte Hermoso (15) and Villa del Mar (16) (Figure 1).

Between September 2002 and March 2003, the localities monitored were 14 including four fishing harbours (localities 2, 11, 12-13 and 17-18) and 10 fishing camps (localities 3-5, 7-10, 14-16) (Figure 1, Table 1).

We interviewed 110 fishermen in 1997-2000 and 99 in 2002-2003 who were present in the harbours and fishing camps. We have considered localities between General Lavalle (1) and Villa Gessell (10) as the Northern Coast and localities between Mar del Plata (11) and Puerto Rosales-Pto. Ingeniero White (17-18) as the Southern Coast. We assumed that the bycatch rate of franciscana estimated for monitored boats was the same as for unmonitored ones in the same locality for the same fishing gear.

\section{Analysis Methods}

We estimated the Fishing Effort (FE), the annual Mortality (M) and the Capture per Unit of Effort (CPUE) in each locality.

To calculate the gillnet fishing effort (FE) of a locality we used the following variables: number of boats $(\mathrm{N})$, mean number of days of active fishing operations (D), and total length of gillnets used during the fishing season by a single boat, in $\mathrm{km}(\mathrm{K})$. The formula applied to obtain $\mathrm{FE}$ is:

$$
\mathrm{FE}=\mathrm{N}^{*} \mathrm{D} * \mathrm{~K}
$$

The shrimper is a different sort of gear in which a funnelshaped net with walls and anchors is set at a stationary tide and is recovered before the next stationary tide (Crespo et al., 1994). To calculate FE for the bottom shrimpers at Ingeniero White-Puerto Rosales and Villa del Mar we used:

$$
\mathrm{FE}=\mathrm{N}^{*} \mathrm{~m}{ }^{*} \mathrm{C}
$$

where $\mathrm{m}$ is months of active fishing operations and $\mathrm{C}$ is number of nets.

Because in some localities the recorded data were obtained from partial surveys, we adjusted each mean of $\mathrm{M}$ and its confidence intervals (CI) to account for both the number of boats and fishing season days not monitored as a straight proportional correction. M CI were calculated for each estimate using a Poisson model (Zar, 1996) following Corcuera et al. (1994) in order to allow comparisons with previous studies:

$$
\begin{gathered}
\text { Upper M CI }=\frac{\chi^{2}(0.025,2(c+1))}{2} \\
\text { Lower M CI }=\frac{\chi^{2}(0.975,2 c)}{2}
\end{gathered}
$$

where $c$ is number of animals bycaught.
Catch per Unit of Effort (CPUE) was estimated for all gears within each locality. The CPUE was calculated as the mortality $(\mathrm{M})$ of the locality divided by the fishing effort (FE) of the same place.

$$
\mathrm{CPUE}=(\mathrm{M} / \mathrm{FE}) * 1000
$$

CPUE CI were obtained by dividing the $\mathrm{CI}$ of $\mathrm{M}$ by the FE recorded for the respective year and locality (Corcuera et al., 1994).

In order to estimate the total mortality and CPUE for the Buenos Aires Province, we pooled data from 19971998 and 1998-2000, as the information of Mar del Plata harbour was available only from 1997-1998. For the northern coast (localities 1-9) we computed the mean mortality estimated for the period 1997-1998 and 1998-2000.

Additionally, the estimated $M$ and CPUE of each surveyed period and area (northern and southern coast) were compared with a non-parametric test as Kruskal Whalis, considering only the localities consistently monitored.

\section{Results}

Table 1 shows the localities surveyed, whether they were working as a fishing harbour or fishing camps for the period 1997-2000 and 2002-2003, the number of coastal operating vessels, the number of vessels interviewed, the gears used and whether there was franciscana bycatch in any one of them, and for how long each locality was surveyed.

In the localities surveyed, mortality was caused at least in one period, by bottom and mid-water gillnets, bottom and mid-water trawls, shrimpers and purse seines (Table 1).

From the 263 vessels operating in the study area in 19972000, 89 operated with bottom gillnet and/or trawling gears (see Table 1), 80 fished with purse seines, 55 used shrimper and the remaining 45 vessels operated with other fishing gears not involved in Franciscana incidental mortality (e.g. long lines, handlines, sport fishing lines, and traps).

From the 263 vessels operating in the study area in 20022003, 162 operated with bottom and mid-water gillnet and trawling gears, one used shrimper gears and the remaining 94 vessels operated with others fishing gears not involved in franciscana incidental mortality, such as longlines, handlines, purse-seines nets and traps (Table 1).

\section{Mortality estimates}

For each locality and period surveyed, the estimated mortality, fishing effort and catch per unit of effort are shown in Tables 2, 3 and 4 respectively, in comparison with data of 1992-1993 from Corcuera (1994). 
Table 2: Mortality (M) detected in the periods 1992-1993, 1997-1998, 1998-2000 and 2002-2003 in each locality, see Map and text for details.

\begin{tabular}{|c|c|c|c|c|c|c|c|c|c|c|c|c|c|}
\hline & \multirow[b]{2}{*}{ LOCALITIES } & \multicolumn{3}{|c|}{ 1992-1993 } & \multicolumn{3}{|c|}{ 1997-1998 } & \multicolumn{3}{|c|}{$1998-2000$} & \multicolumn{3}{|c|}{$2002-2003$} \\
\hline & & M & $\begin{array}{c}\mathrm{CI} \\
\mathrm{min}\end{array}$ & $\begin{array}{c}\mathrm{CI} \\
\max \end{array}$ & M & $\begin{array}{c}\mathrm{CI} \\
\mathrm{min}\end{array}$ & $\begin{array}{c}\mathrm{CI} \\
\max \end{array}$ & M & $\begin{array}{c}\mathrm{CI} \\
\mathrm{min}\end{array}$ & $\begin{array}{c}\mathrm{CI} \\
\max \end{array}$ & M & $\begin{array}{c}\mathrm{CI} \\
\mathrm{min}\end{array}$ & $\begin{array}{c}\mathrm{CI} \\
\max \end{array}$ \\
\hline 1 & General Lavalle & - & - & - & 1.00 & 0.03 & 5.57 & 3.00 & 0.60 & 9.50 & - & - & - \\
\hline 2 & San Clemente del Tuyu & - & - & - & 58.00 & 44.40 & 74.98 & 94.00 & 75.90 & 115.00 & 127.50 & 106.35 & 151.65 \\
\hline 3 & Las Toninas & - & - & - & 21.00 & 13.00 & 32.10 & 16.00 & 9.10 & 26.00 & 4.00 & 1.09 & 10.24 \\
\hline 4 & Santa Teresita & - & - & - & 27.00 & 17.79 & 39.28 & 21.00 & 13.00 & 32.10 & 7.50 & 3.13 & 15.10 \\
\hline 5 & Mar del Tuyú & - & - & - & 16.20 & 9.15 & 25.94 & 19.50 & 11.80 & 30.30 & 8.00 & 3.45 & 15.77 \\
\hline 6 & Aguas Verdes & - & - & - & 5.25 & 1.91 & 12.37 & - & - & - & - & - & - \\
\hline 7 & La Lucila del Mar & - & - & - & 3.50 & 0.85 & 9.51 & 4.00 & 1.10 & 10.20 & 12.00 & 6.20 & 20.96 \\
\hline 8 & San Bernardo & - & - & - & 14.00 & 7.65 & 23.49 & 26.00 & 17.00 & 38.10 & 19.00 & 11.44 & 29.67 \\
\hline 9 & Mar de Ajó & - & - & - & 49.00 & 36.25 & 64.78 & 25.00 & 16.20 & 36.90 & 17.00 & 9.91 & 27.22 \\
\hline 10 & Villa Gesell & - & - & - & - & - & - & - & - & - & 6.00 & 2.20 & 13.06 \\
\hline 11 & Mar del Plata & - & - & - & 15.00 & 8.40 & 24.74 & - & - & - & 42.50 & 30.70 & 57.35 \\
\hline $\begin{array}{l}12 \\
13\end{array}$ & Quequén - Necochea & 4.70 & 1.40 & 11.00 & - & - & - & 13.00 & 6.90 & 22.20 & 0.00 & 0.00 & 3.69 \\
\hline 14 & Claromecó & 34.00 & 23.50 & 47.50 & - & - & - & 7.50 & 3.10 & 15.10 & 3.33 & 0.77 & 9.27 \\
\hline 15 & Monte Hermoso & 91.50 & 73.70 & 112.30 & - & - & - & 30.00 & 20.20 & 42.80 & 11.78 & 6.05 & 20.68 \\
\hline 16 & Villa del Mar & 14.00 & 7.70 & 23.50 & - & - & - & 1.00 & 0.00 & 5.60 & 0.00 & 0.00 & 3.69 \\
\hline $\begin{array}{l}17 \\
18\end{array}$ & $\begin{array}{l}\text { Puerto Rosales } \\
\text { - Ingeniero White }\end{array}$ & 85.50 & 68.30 & 105.70 & - & - & - & 83.00 & 66.10 & 102.90 & 48.00 & 35.39 & 63.65 \\
\hline
\end{tabular}

TOTAL

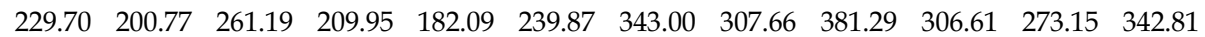

The $95 \%$ confidence limits intervals are shown.

\section{Bahía Samborombón}

This area includes two of the localities surveyed that caused incidental mortality: General Lavalle and San Clemente del Tuyú. All the 34 vessels operating in Bahía Samborombón were interviewed in 1997-2000. Most of the fishermen used bottom trawls (Table 1). In 2000 only three boats from General Lavalle and six from San Clemente del Tuyú were operating with gillnets that were set for three months, from October to December. According to our interviews each vessel sets 300-700 metres of net with a mesh size of $16 \mathrm{~cm}$. Their target species was the white croacker (Micropogonias furnieri).

During 2002-2003, the black drum (Pogonias cromis) was also targeted in gillnet fisheries with mesh sizes of 27 and $30 \mathrm{~cm}$ operating from San Clemente del Tuyú.

In General Lavalle mortality estimates were always low, but the fishing effort increased from 1997-1998 to 1998-2000.

San Clemente del Tuyú showed the highest mortality levels of all sampled periods. In 1998-2000 it was caused by the only three vessels operating with bottom gillnets. The fishing effort was nearly the same during 1997-2000, but the CPUE was quite different. From six vessels causing this high mortality, the one causing the greatest incidental catch $(64 \%)$ is no longer using this gear but changed to longline. On the other hand, in 2002-2003 the fishing effort increased almost three times compared to the previous periods and the catch per unit of effort decreased.

\section{Cabo San Antonio}

Cabo San Antonio is an extensive coast only small 
fishing camps including: Las Toninas, Santa Teresita, Mar del Tuyú, Aguas Verdes, La Lucila del Mar, San Bernardo and Mar de Ajó. Although the number of small vessels using gillnets in the entire area was similar along the periods, the fishing camp of Aguas Verdes no longer operates since 1998 and there were slight differences per locality. The fishing ground of these small fishing camps overlapped with those of neighboring localities. Fishermen used exclusively gillnet and trawling gears and targeted several species (sharks, teleosts, rays) setting approximately $200 \mathrm{~m}$ of net/day of a mesh size of 12,14 or $15 \mathrm{~cm}$. They were generally active in spring and summer and the catch was usually sold to tourists. Although incidental catches of franciscana decreased during the surveys, mortality for the entire area was high between 1997 and 2000, with more than 100 dolphins incidentally caught each year. However, in 2002-2003 it was lower. Effort was lower in 1998-2000 in comparison to the previous survey (1997-1998). In contrast, the fishing effort was higher in 2002-2003 despite the fewer number of vessels. Mortality levels have shown to be higher in Mar de Ajó, followed by Santa Teresita, and San Bernardo in 1997-2000. On the other hand, in 2002-2003, San Bernardo showed the highest mortality followed by Mar de Ajó and La Lucila del Mar. The CPUE of the entire area decreased throughout the years.

\section{Mar del Plata}

This is an important harbour with a large fleet of up to 90 artisanal vessels in 1997-1998. Most of them operated with purse-seine nets, and only some of them with gillnets. At this harbour mortality was associated with purse-seines, where nets were operated by two cooperating vessels being the mackerel (Scomber japonicus) and anchovies (Engraulis anchoita) their target species (see Table 1). The fishing season was short, from October to November. During 2002-2003, 85 vessels were recorded in the harbour, most of them (see Table 1) operating with gillnets targeting sharks, which were responsible for the incidental mortality of franciscana. In contrast, in this last period, no bycatch were recorded in purse seine nets. The mortality increased because of the great increase of gillnets fishing effort.

\section{Puerto Quequén - Necochea}

During 1998-2000, 82\% of the coastal vessels ( $n=18$, see Table 1) were operating with bottom and mid-water trawling and no franciscana was killed in this kind of gear. There were only four vessels operating with gillnets targeting sharks which set $2500 \mathrm{~m}$ of net/day during spring months. Thirteen dolphins were killed in 1998-2000 but no dolphin was caught by the nine vessels recorded during the 2002-2003 survey.

Table 3: Fishing effort detected in the periods 1992-1993, 1997-1998, 1998-2000 and 2002-2003 in each locality, see Map and text for details.

\begin{tabular}{llcccc}
\hline \hline & & \multicolumn{4}{c}{ FISSHING EFFORT } \\
& LOCALITIES & $1992-1993$ & $1997-1998$ & $1998-2000$ & $2002-2003$ \\
\hline \hline 1 & General Lavalle & - & 9.30 & 63.00 & - \\
\hline 2 & San Clemente del Tuyu & - & 137.50 & 129.00 & 384.00 \\
\hline 3 & Las Toninas & - & 70.80 & 67.38 & 72.00 \\
\hline 4 & Santa Teresita & - & 26.25 & 59.94 & 114.00 \\
\hline 5 & Mar del Tuyú & - & 15.75 & 57.32 & 64.50 \\
\hline 6 & Aguas Verdes & - & 19.00 & - & - \\
\hline 7 & La Lucila del Mar & - & 15.75 & 23.60 & 63.00 \\
\hline 8 & San Bernardo & - & 45.00 & 31.50 & 105.00 \\
\hline 9 & Mar de Ajó & - & 115.80 & 54.44 & 79.80 \\
\hline 10 & Villa Gesell & - & - & - & 162.00 \\
\hline 11 & Mar del Plata & - & 450.00 & - & 2550.00 \\
\hline 12 & Quequén - Necochea & 1215.00 & - & 445.20 & 1000.00 \\
13 & & & & & \\
\hline 14 & Claromecó & 724.50 & - & 63.00 & 160.00 \\
\hline 15 & Monte Hermoso & 178.40 & - & 180.00 & 1344.00 \\
\hline 16 & Villa del Mar & 187.50 & - & 94.50 & 108.00 \\
\hline 17 & Puerto Rosales - Ingeniero White & 2038.50 & - & 6720.00 & 2160.00 \\
18 & & 4343.90 & 905.15 & 7988.88 & 8366.30 \\
\hline \hline & TOTAL & & & & \\
\hline \hline
\end{tabular}


Table 4: Catch per unit of effort (CPUE) X 1000 of franciscanas, detected in the periods 1992-1993, 1997-1998, 1998-2000 and 2002-2003 in each locality, see Map and text for details.

\begin{tabular}{|c|c|c|c|c|c|c|c|c|c|c|c|c|c|}
\hline & \multirow[b]{2}{*}{ LOCALITIES } & \multicolumn{3}{|c|}{ 1992-1993 } & \multicolumn{3}{|c|}{ 1997-1998 } & \multicolumn{3}{|c|}{$1998-2000$} & \multicolumn{3}{|c|}{$2002-2003$} \\
\hline & & CPUE & $\mathrm{CI} \min$ & CI max & CPUE & $\mathrm{CI} \min$ & CI max & CPUE & $\mathrm{CI} \min$ & $\mathrm{CI} \max$ & CPUE & $\mathrm{CI} \min$ & $\mathrm{CI} \max$ \\
\hline 1 & General Lavalle & - & - & - & 107.50 & 88.2 & 129.96 & 47.62 & 35.00 & 63.10 & - & - & - \\
\hline 2 & $\begin{array}{l}\text { San Clemente del } \\
\text { Tuyu }\end{array}$ & - & - & - & 421.80 & 382.5 & 464.04 & 728.68 & 676.70 & 783.80 & 332.03 & 276.95 & 394.92 \\
\hline 3 & Las Toninas & - & - & - & 296.61 & 263.80 & 332.35 & 237.46 & 208.30 & 269.70 & 55.56 & 15.14 & 142.24 \\
\hline 4 & Santa Teresita & - & - & - & 1028.60 & 966.3 & 1093.0 & 350.35 & 314.70 & 389.10 & 65.79 & 27.46 & 132.41 \\
\hline 5 & Mar del Tuyú & - & - & - & 1028.60 & 966.3 & 1093.0 & 340.20 & 305.00 & 378.30 & 124.03 & 53.54 & 244.42 \\
\hline 6 & Aguas Verdes & - & - & - & 274.40 & 243.0 & 308.97 & - & - & - & - & - & - \\
\hline 7 & La Lucila del Mar & - & - & - & 222.20 & 193.9 & 253.4 & 169.49 & 145.00 & 197.00 & 190.48 & 98.41 & 332.70 \\
\hline 8 & San Bernardo & - & - & - & 311.10 & 277.5 & 347.7 & 825.40 & 770.00 & 883.70 & 180.95 & 108.95 & 282.57 \\
\hline 9 & Mar de Ajó & - & - & - & 423.10 & 465.4 & 383.8 & 459.22 & 418.20 & 503.20 & 213.03 & 124.12 & 341.10 \\
\hline 10 & Villa Gesell & - & - & - & - & - & - & - & - & - & 37.04 & 13.59 & 80.62 \\
\hline 11 & Mar del Plata & - & - & - & 33.30 & 23.15 & 46.90 & - & - & - & 16.67 & 12.04 & 22.49 \\
\hline $\begin{array}{l}12 \\
13\end{array}$ & $\begin{array}{l}\text { Quequén - } \\
\text { Necochea }\end{array}$ & 3.90 & 1.10 & 9.00 & - & - & - & 29.20 & 19.40 & 41.70 & 0.00 & 0.00 & 3.69 \\
\hline 14 & Claromecó & 46.90 & 32.50 & 65.60 & - & - & - & 119.05 & 98.60 & 142.40 & 20.83 & 4.80 & 57.91 \\
\hline 15 & Monte Hermoso & 512.90 & 413.20 & 629.40 & - & - & - & 166.67 & 142.40 & 194.00 & 8.76 & 4.50 & 15.39 \\
\hline 16 & Villa del Mar & 74.70 & 40.80 & 125.30 & - & - & - & 10.58 & 5.14 & 19.04 & 0.00 & 0.00 & 34.16 \\
\hline \multirow[t]{2}{*}{$\begin{array}{l}17 \\
18\end{array}$} & $\begin{array}{l}\text { Puerto Rosales - } \\
\text { Ingeniero White }\end{array}$ & 41.94 & 30.22 & 56.70 & - & - & - & 12.35 & 6.56 & 21.60 & 22.22 & 16.38 & 29.47 \\
\hline & TOTAL & 52.88 & 39.27 & 68,76 & 231,95 & 202,64 & 263,32 & 42,93 & 30,70 & 57,35 & 36.65 & 32.65 & 40.98 \\
\hline
\end{tabular}

The 95\% confidence limits intervals are shown.

\section{Claromecó}

In this small fishing camp there were 4-5 small vessels 10-meter long operating with traps and hand dredges during the entire survey. The other 5-10 boats 5-meter long were all working with gillnets for small sharks (as the narrownose smooth-hound Mustelus schmitti), setting $150 \mathrm{~m}$ of net/day of $9-10.5 \mathrm{~cm}$ of mesh size. The estimated bycatch decreased from 34 to 3 dolphins per year, throughout the survey. The CPUE of 2002-2003 showed a decrease of more than $80 \%$ compared to the 1998-2000 survey.

\section{Monte Hermoso}

Twelve and nine boats used gillnets with mesh size of 10-22cm in 1998-2000 and 2002-2003, repectively. Although FE increased almost 7.5 times franciscana mortality decreased considerably from 1998-2000 to 2002-2003.

\section{Villa del Mar}

Franciscana mortality was also low in this fishing camp.
Incidental catch was reported in the 1998-2000 period. In the last surveyed period, two vessels fished with gillnet, setting $350 \mathrm{~m}$ of net/day but no mortality was reported.

\section{Ingeniero White and Puerto Rosales}

Ingeniero White is a large fishing harbour inside the Bahía Blanca estuary. Puerto Rosales is a small fishing camp with only three boats operating with gillnets in 1998-2000. This small harbour is close to Ingeniero White and their fishing ground overlap.

The fishing gear that caused mortality in Ingeniero White-Puerto Rosales, during the 1998-2000 survey, was the shrimper bottom trawl, operating with 12 nets / day. In 2002-2003, the fleet was composed by 60 vessels fishing with gillnet gears except one of them that used a shrimper. The estimated mortality decreased through time.

\section{Global mortality in the study area}

The global M and CPUE for the northern and southern coasts of each period are shown in Figure 2, compared 
with data from 1992-1993 (Corcuera, 1994).

The total mortality estimated for the 1997-2000 period in bottom gillnets, purse-seines and bottom trawls was 354 dolphins per year (95\% CI = 318-392) for the Buenos Aires Province (Northern Coast: 204, 95\% CI =177-234; Southern Coast: $150,95 \% \mathrm{CI}=127-175)$. The total CPUE for this period was $42(95 \% \mathrm{CI}=38-47)$.

During 2002-2003 period the estimated total mortality was 307 dolphins per year (95\% CI = 273-343; Northern Coast: $201,95 \%$ CI $=174-231$; Southern Coast: 106, 95\% $\mathrm{CI}=86-128)$. The total CPUE for this period was 37 (95\% CI $=33-41)$.

For both surveyed period, CPUE of the northern coast was significantly higher than CPUE for the southern coast (Kruskal Wallis test, 1997-2000: $\mathrm{H}=8.68$, $\mathrm{p}=0.0032$; 2002-2003: $\mathrm{H}=9.82, \mathrm{p}=0.0017)$. In addition, CPUE of the northern coast of 1997-2000 was significantly higher than for 2002-2003 (Kruskal Wallis test, $\mathrm{H}=7.55, \mathrm{p}=0.0060$ ) and for the southern area CPUE values were significantly lower in 2002-2003 (Kruskal Wallis test, $\mathrm{H}=3.97, \mathrm{p}=0.0465)$.

\section{Discussion and Conclusions}

We surveyed $62 \%$ of the coastal vessels including bottom gillnet, shrimpers, trawling and purse seine nets. Mortality levels were related to the fishing effort and these values change with the fleet behaviour, mostly in the fishing camps, as the number of vessels and effective fishing days change among years (Tables 1 and 3).

Highest mortality was estimated for San Clemente del Tuyú. Therefore, Bahía Samborombón is an area to develop further studies in order to verify whether this pattern in which very few vessels are responsible for most of the captures is true or not. Thus, the largest part of mortality could be mitigated by means of changing

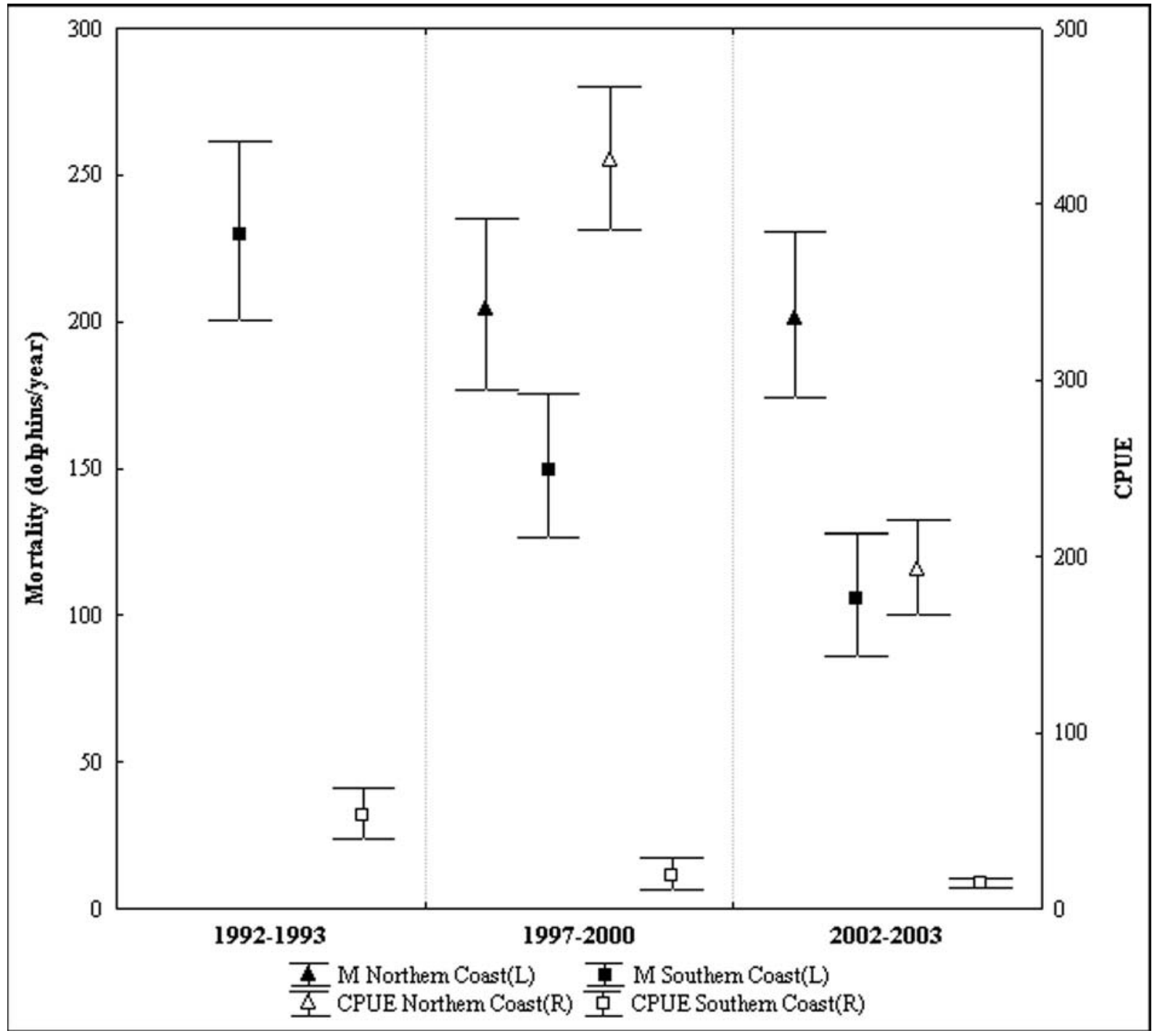

Figure 2: Mortality, as dolphins captured incidentally per year, and CPUE measured along the northern and southern coast of the Buenos Aires Province for each period surveyed. Data from 1992-1993 are taken from Corcuera (1994). 
the fishing grounds of a few vessels.

Although the fishing season was shorter and the amount of gears per boat was lower, the mortality levels and the number of boats at Cabo San Antonio area remained constant from 1997 to 2000 . Fishermen of this area stated that they were facing two problems: the presence of the South American sea lion (Otaria flavescens) causing important damages on their nets (Crespo et al., 1994) and the presence of vessels from the Mar del Plata harbour operating in their fishing grounds. In 2002-2003, the mortality decreased by $35 \%$ but the fishing effort increased more than that in the previous periods.

The mortality estimated for the southern area was lower in 1997-2000 as compared to previous estimations of 1992-1993 (Table 3, Corcuera et al., 1994) with CPUE values significantly lower in 2002-2003. The collapse of shark fisheries (Chiaramonte, 1998) around the fishing grounds near Necochea and Puerto Quequén area has led fishermen to move to the fishing grounds further offshore and to replace gillnets by bottom trawls. Thus, the lower CPUE levels in gillnets might be a result of fishing gears set further offshore.

From Mar del Plata harbour operates the most important fishing fleet along the coast. The increased in fishing effort showed during the last years probably caused most of the franciscana mortality, but additional monitoring is necessary.

Claromecó used to be a fishing camp with high reported franciscana bycatch (Corcuera, 1994), but the current estimation suggests a decrease (Table 3 ). This might be due to the collapse of the shark fishery that caused high franciscana mortality in the early 1990s. Fishermen who continued operating with gillnets were using smaller mesh sizes (18-36cm for Corcuera, 1994 vs $9-10.5 \mathrm{~cm}$ in this study) which is suspected to be less harmful to franciscana (e.g. Praderi et al., 1989). In addition, as observed in Cabo San Antonio, damage to fishing gear caused by South American sea lions have forced fishermen to reduce fishing effort.

Monte Hermoso showed lower mortality and CPUE levels than those estimated for the 1992-1993 period (Tables 3 and 4). There were no changes in fishing grounds, so the decrease in mortality values might be related to changes in the gillnet mesh size $(10 \mathrm{~cm}$ compared with the $22 \mathrm{~cm}$ of mesh size used earlier, Corcuera, 1994). Fishermen had the same problems as those from Cabo San Antonio because of the presence of the South American sea lion severely damaging their nets and the presence of vessels from Mar del Plata whose fishing grounds overlap those of local fishermen. Corcuera (1994) estimated for Villa del Mar that 6 vessels caused a mortality of 14 dolphins (95\% CI = 8-24) with gillnet gears. In this study, the bycatch of only one franciscana was recorded in a shrimper and none in gillnets.

At Ingeniero White and Puerto Rosales harbours the mortality levels remain high (Table 3), although the survey effort in the last period was low and beyond the changes in the fishing gears that alternate from shrimpers to gillnets (Table 1). Artisanal fisheries still prove to be a potential threat to the conservation of franciscana in this harbour as shown by our results from 1997-2000 and the estimations of Corcuera (1994) for the 1992-1993 period.

The global mortality for the northern coast of Buenos Aires Province seems not to show important changes in the estimated mortality (Figure 2). However, the CPUE level of that area in 1997-2000 was significantly higher than 2002-2003, possibly as a result of a higher FE that was not followed by a linear mortality during the last surveyed period.

Additionally, the CPUE on the southern coast was significantly lower than that of the northern coast in both surveyed periods (Figure 2).

As in other parts of the world, there is a tendency of underreporting dolphin bycatch in Argentina. Because of that, our figures should be considered a minimum mortality of franciscana in this region. Nevertheless, if we compare values obtained in this study with results of onboard observations (Bordino and Albardeda, 20045) we obtain a similar mortality rate: those authors estimated a mortality of 175 dolphins/year for the period 2002-2003 vs. 195 (95\% CI = 169-224) estimated for the same period in this study in the northern area (excluding Villa Gessell). Consequently, both methods (onboard observations and interviews) allowed us to obtain a similar result. However, the mortality estimation from the entire Province does show differences with Bordino and Albareda $\left(2004^{5}\right)$ as these authors extrapolated the northern mortality estimations to the southern coasts, considering them similar.

Mortality levels could be important at each local population or stock and the conservation policy must be implemented locally. It is urgent to obtain data about franciscana stock identity in order to articulate programs of conservation for the species.

Franciscana shows a continuous presence along the coastal area of Buenos Aires Province (Corcuera, 1994). Recent studies conducted by Lázaro et al. (2004) and Ott et al. $(2005)^{8}$ described a substantial geographic heterogeneity in its distribution, particularly in the southern Buenos Aires Province, suggesting this area should be considered separately. Moreover, Mendez et al. (2007) suggest that the franciscana population in

\footnotetext{
${ }^{8}$ Ott, P.H., Freitas, T.R.O., Secchi, E.R., Lázaro, M., Bastida, R., Di Beneditto, A.P.M., Zanelatto, R.C., Bordino, P., Vicente, A.F.C., Ramos, R.M.A. and White, B.N. (2005) Estructura populacional de Toninha (Pontoporia blainvillei) baseada na análise de DNA mitocondrial e nuclear. DT $\mathrm{N}^{\mathrm{o}} 3$ in Abstracts, V Taller para la Coordinación de la Investigación y Conservación del delfín Franciscana (Pontoporia blainvillei) en el Atlántico Sudoccidental, 28-30 November, Mar del Plata, Argentina.
} 
northern Buenos Aires is the most isolated population in Argentina and their results support the current scheme of larger recognized Franciscana Management Areas (FMA), but argue for a finer-scale subdivision within Northern Buenos Aires region (FMA IV).

The International Whaling Commission Scientific Committee (Donovan and Bjørge, 1995) has noted that incidental mortality estimates of $1 \%$ per year of an estimated population size are sufficient to concern over the status of small cetacean population and the catches of $2 \%$ per year may not be sustainable.

This study suggests that, even though the gears or fleet behaviour changed locally, the overall mortality in the Buenos Aires Province was relatively constant during the surveyed periods, considering the areas consistently monitored and therefore feasible of being compared.

A maximum estimated annual mortality of nearly 400 individuals corresponds to more than $2 \%$ of the stock of Argentina, suggesting that the population of franciscana in this country may be vulnerable. Taking into account that some species under pressure of extensive bycatch increase their growth rate (Caswell et al., 1998), the current effect of incidental mortality by artisanal fisheries on the sustainability of franciscana stock of southern Buenos Aires Province remain uncertainty until more population data become available.

Argentina is lacking and needs a policy for the management of fisheries that include the bycatch of nontarget species (Crespo et al., 1994, 1997, 2000). Thus, identification of alternative fishing grounds and gears are of great importance. An education program focused to show and disseminate these alternatives to the fishermen communities should be developed. All these efforts should be urgently focused on the areas with high mortality, that is, those centered on San Clemente del Tuyú-Cabo San Antonio, Necochea-Puerto Quequén and Monte Hermoso-Bahía Blanca estuary.

\section{Acknowledgments}

This project was founded by grants to HLC from Fundación Antorchas, Proyecto A-13672/1-3 from Argentina (survey at southern coast) and to JFC and FM from ONG Yaqu Pacha from Germany (survey at northern coast). We (HLC) obtained additional financial support from the Convention of Migratory Species (CMS) and Fundación Vida Silvestre Argentina. We thank E. Crespo, A. Schiavini for their useful comments and suggestions to improve the manuscript. We thank Eduardo Secchi, Alexandre Zerbini, Nelio Barros and an anonymous referee for their helpful comments on the manuscript. We thank P. Bordino, G. Chiaramonte, L. Tamini, J. E. Perez, A. Averbuj, A. J. Alarcos, M. Iurman, E. Bocci and F. Romeo for their help at field work. We also thank the
Bertazzo family from Monte Hermoso for their hospitality and information about those fishing camps. This study was possible by the help given by fishermen and skippers from fishing vessels along the Buenos Aires Province coast. Logistical support given by IADO (Instituto Argentino de Oceanografía from Bahía Blanca), Cintia Piccolo (Director of IADO) and its technical personnel (Sr. Camilo Bernardez and Sr. "Beto") help us during the Bahía Blanca survey. We thank Prefectura Naval Argentina for allowing us to carry on this research along the coast. This is a scientific contribution of the Estación Hidrobiológica de Puerto Quequén on its $80^{\text {th }}$ anniversary.

\section{References}

Albareda, D.A. and Albornoz, N. (1994) Mortalidad de franciscanas en la pesquería artesanal de San Bernardo y Mar de Ajó - Prov. De Buenos Aires- Argentina. Pages 54-61 in Pinedo, M.C. e A.S. Barreto (Eds), Anais do $2^{\circ}$ Encontro sobre coordenação de pesquisa e manejo da franciscana, Florianópolis, SC, Brazil.

CASWEll, H., BROULT, S., ReAD, A.J. AND SMith, T.S. (1998) Harbor porpoise and fisheries: an uncertainty analysis of incidental mortality. Ecological Applications 8: 1226-1238.

Chiaramonte, G.E. (1998) Shark fisheries in Argentina. Marine and Freshwater Research 49: 601-609.

Corcuera, J.F. (1994) Incidental mortality of franciscana dolphin in Argentine waters: the threat of small fishing camps. Pages 291-294 in Perrin, W.P., Donovan, G.P. And Barlow, J. (Eds) Gillnets and Cetaceans. Report of the International Whaling Commission (Special Issue 15), Cambridge, U.K.

Corcuera, J.F., Monzón, F., Crespo, E., Aguilar, A. and Raga, J. (1994) Interactions between marine mammals and the coastal fisheries of Necochea and Claromecó. Pages 283-290 in PERRIN, W.P., Donovan, G.P. AND BARLOW, J. (Eds) Gillnets and Cetaceans. Report of the International Whaling Commission (Special Issue 15), Cambridge, U.K.

Crespo, E.A., Corcuera, J.F. And López Cazorla, A. (1994) Interactions between marine mammals and fisheries in some coastal fishing areas of Argentina. Pages 269-281 in PERrin, W.P., Donovan, G.P. AND BARLOW, J. (Eds) Gillnets and Cetaceans. Report of the International Whaling Commission (special issue 15), Cambridge, U.K.

Crespo, E.A., Pedraza, S.N., Dans, S.L., Koen Alonso, M., Reyes, L.M., Garcia, N.A., Coscarella, M and Schiavini, A.C.M. (1997) Direct and indirect effects of the highseas fisheries on the marine mammal populations in the northern and central Patagonian Coast. Journal of the Northwest Atlantic Fishery Science 22: 189-207.

Crespo, E.A., Harris, G. AND GonZÁlez, R. (1998) Group size and distribution range of the franciscana, Pontoporia blainvillei. Marine Mammal Science 14(4): 845-849.

Crespo, E.A., Koen Alonso, M., Dans, S.L., García, N.A., Pedraza, S.N., Coscarella, M.A. and González, R. (2000) Incidental catch of dolphins in mid-water trawls for southern anchovy of Patagonia. Journal of Cetacean Research and Management 2(1):11-16. 
Donovan, G.P. And BJørge, A. (1995) Dall's porpoise, Phocoenoides dalli - Introductory remarks. Pages 378-380 in Bjørge, A. And Donovan, G.P. (Eds.) Biology of the Phocoenids. Report of the International Whaling Commission (special issue 16), Cambridge, U.K.

Lázaro, M., Lessa, E.P. and Hamilton, H. (2004) Geographic genetic structure in the franciscana dolphin (Pontoporia blainvillei). Marine Mammal Science 20(2): 201-214.

Mendez, M., Rosenbaum, H.C. And Bordino, P. (2008) Conservation genetics of the franciscana dolphin in Northern Argentina: population structure, by-catch impacts, and management implications. Conservation Genetics 9(2): 419-435.

Monzón, F. And Corcuera, J.F (1991) Franciscana Pontoporia blainvillei (Gervais and d'Orbigny, 1844). Pages 16-22 in Cappozzo, H.L. And Junín, M. (Eds.) Estado de conservación de los mamíferos marinos del Atlántico sudoccidental. Informes y estudios del Programa de Mares Regionales del PNUMA No 138.

Pérez Macri, G. and Crespo, E.A (1989) Survey of the franciscana, Pontoporia blainvillei, along the Argentine coast, with a preliminary evaluation of mortality in coastal fisheries. Occasional papers IUCN SSC 3: 57-63.

Pinedo, M.C., Praderi, R. ANd Brownell, JR., R.L. (1989) Review of the biology and status of the franciscana Pontoporia blainvillei.
Pages 46-51 in Perrin, W.F., Brownell, R.L., Zhou, K. And Liu, J. (Eds) Biology and conservation of the river dolphins. IUCNSpecies Survival Commission, Occasional papers IUCN SSC 3.

Praderi, R., Pinedo, M.C. ANd CRespo, E.A. (1989) Conservation and Management of Pontoporia blainvillei in Uruguay, Brazil and Argentina. Pages 52-56 in Perrin, W.F., Brownell, R.L., ZHOU, K. AND LIU, J. (Eds) Biology and conservation of the river dolphins. IUCN-Species Survival Commission, Occasional papers IUCN SSC 3.

Rosas, F.C.W., Monteiro Filho, E.L.A. and Oliveira, M.R. (2002) Incidental catches of franciscana (Pontoporia blainvillei) on the southern coast of São Paulo State and the coast of Paraná State, Brazil. The Latin American Journal of Aquatic Mammals 1(1): 161-167.

Secchi, E.R., Zerbini, A.N., Bassoi, M., Dalla Rosa, L., Moller, L.M. And Rocha-CAmpos, C.C. (1997) Mortality of franciscanas, Pontoporia blainvillei, in coastal gillnetting in southern Brazil: 1994-1995. Report of the InternationalWhaling Commission 47: 653-658.

Siciliano, S. (1994) Review of small cetaceans and fishery interactions in coastal waters of Brazil. Report of the International Whaling Commission 15: 241-250.

ZAR, J.H. (1996) Biostatistical analysis. 3rd Edition. Prentice-Hall Inc. Upper Saddle River, NJ , USA. 662 pp. 
